\title{
THE STRUCTURE AND COMPOSITION OF PROTEIN BODIES PURIFIED FROM BARLEY ENDOSPERM BY SILICA SOL DENSITY GRADIENTS
}

\author{
by
}

\author{
VERENA CAMERON-MILLS
}

Department of Physiology, Carlsberg Laboratory

Gamle Carlsberg Vej 10, DK-2500 Copenhagen Valby

Keywords: Protein bodies, hordein, high-lysine mutants, silica sol gradients

A Percoll density gradient has been devised for the separation of protein bodies from cytoplasmic membrane components of barley endosperm. Protein bodies band isopycnically at a density of $1.13 \mathrm{~g} . \mathrm{ml}^{-1}$, whereas stripped and smooth microsomes band at a density of $1.05 \mathrm{~g} \cdot \mathrm{ml}^{-1}$ in a sigmoidal Percoll density gradient generated in situ. Sucrose density gradients are shown to be unsuitable for the isolation of immature barley protein bodies owing to the isopycnic banding of smooth microsomes together with immature protein bodies at a density of $1.18 \mathrm{~g} \cdot \mathrm{ml}^{-1}$.

The complex ultrastructure of protein bodies observed in situ in barley endosperm is preserved in the isolated protein bodies prepared from Bomi and Carlsberg II barley and their high-lysine mutants Risø 1508 and Risø 56 , respectively. The changes in protein body structure observed in these high-lysine mutants are thought to reflect the qualitative and quantitative changes in hordein biosynthesis caused by these gene mutations.

Electrophoretic analysis of the polypeptide composition of the purified protein bodies reveals that all the major hordein polypeptides synthesized in barley endosperm are stored in protein bodies. However, several additional polypeptides, which are not hordein, are specifically associated with protein bodies of each barley genotype.

\section{INTRODUCTION}

Hordein polypeptides, which comprise major storage proteins of barley grain, are deposited in the developing endosperm cell as protein bodies
$(10,17,25)$. The hordeins are synthesized on the endoplasmic reticulum, co-translationally transported into its lumen, and from there transferred into the vacuoles of the cells $(5,17,25)$. While it

Abbreviations: DTT $=$ dithiothreitol; HEPES $=\mathrm{N}$-2-hydroxyethylpiperazine-N'-2-ethane sulfonic acid: HK = HEPES-K acetate buffer (see 2.1.); SDS-PAGE = Sodium dodecylsulfate polyacrylamide gel electrophoresis; Tris $=$ tris(hydroxymethyl)aminomethane; TCA = trichloracetic acid. 
is becoming clear that many plant storage proteins are synthesized on the endoplasmic reticulum $(2,14,19)$ in a similar manner to secretory proteins in animal cells (1), the mechanism and pathway of transport to the site of deposition has yet to be elucidated. The hordein polypeptides are extremely hydrophobic, being rich in glutamine and proline residues (20). It is thus of great interest to discover how these polypeptides are transported through the aqueous environment of the endoplasmic reticulum cisternae and how their precipitation is delayed until they are finally released into a cell vacuole. There is no evidence from ultrastructural studies (25) to suggest that hordein precipitates in the lumen of the endoplasmic reticulum to be budded off in the form of membrane-bound protein bodies as has been proposed for zein deposition in maize endosperm $(4,13)$.

Protein bodies have a complex structure, described as an aggregate of homogeneous components embedded in a granular or fibrillar matrix and often associated with small dense spheres $(17,25)$. It has been suggested that this complex architecture reflects the progressive precipitation and condensation of hordein and other storage polypeptides, yielding a largely homogeneous structure at maturity. In order to investigate the precise composition of developing protein bodies, techniques to purify them at different stages of maturity have been devised.

Mutant barley lines selected for their highlysine character, are deficient in hordein biosynthesis (12). Detailed analysis of these mutants reveals that synthesis of either one or both of the ' $\mathrm{B}$ ' and ' $\mathrm{C}$ ' hordein polypeptide subgroups may be influenced, reflecting the presence of two structural gene loci, hor- 2 and hor-l respectively (7). Since the 'B' and ' $C$ ' hordein polypeptides have different amino acid compositions and solubility properties $(20,23)$ their contribution to the structure and formation of protein bodies could be investigated with the aid of specific high-lysine barley mutants.

\section{MATERIALS AND METHODS}

\subsection{Chemicals}

HEPES, sucrose, DTT and EDTA were purchased from Sigma Chemicals and Percoll (colloidal silica sol coated with polyvinylpyrroli- done) with density marker beads from Pharmacia Fine Chemicals.

HK buffer A: 20 mm-HEPES, pH 7.6, 100 $\mathrm{mM}-\mathrm{K}$ acetate and $5 \mathrm{~mm}-\mathrm{Mg}$ acetate.

HK buffer B: 20 mm-HEPES, pH 7.6, 100 $\mathrm{mm}-\mathrm{K}$ acetate, $5 \mathrm{~mm}$-EDTA and $0.25 \mathrm{M}$-sucrose.

HK buffer C: 200 mM-HEPES, pH 7.6, $1 \mathrm{M}-\mathrm{K}$ acetate, $50 \mathrm{~mm}$-EDTA and $2.5 \mathrm{~m}$-sucrose.

\subsection{Plant material}

Barley plants (Hordeum vulgare L.) cv. Bomi and its mutant Risø 1508 (lys 3a) and cv. Carlsberg II and its mutant Risø 56 were grown in the field. Spikes were harvested 20 days (wild type) or 25 days (mutants) after anthesis, frozen in liquid nitrogen and stored in polyethylene bags at $-70^{\circ} \mathrm{C}$ for up to three months.

\subsection{Subcellular fractionation of barley endosperm and isolation of protein bodies}

Endosperms were squeezed from 10 spikes and ground to a powder in a mortar cooled with liquid nitrogen. The ground endosperms were suspended in $25 \mathrm{ml} \mathrm{HK}$ buffer A containing 0.2 $\mathrm{M}$-sucrose, and maintained at $0-4{ }^{\circ} \mathrm{C}$ in all subsequent steps. The suspensions were centrifuged at $500 \times \mathrm{g}_{\mathrm{av}}$ for $10 \mathrm{~min}$ in a Sorvall SS-34 rotor to remove most of the starch, cell walls and unbroken cells. The supernatants were layered on a $10 \mathrm{ml} 2.26 \mathrm{M}$-sucrose cushion made up in $\mathrm{HK}$ buffer $\mathrm{A}$ and centrifuged at $10,000 \times \mathrm{g}_{\mathrm{av}}$ on a Beckman SW 27 rotor for $20 \mathrm{~min}$. Material banding on the sucrose cushion interface was collected for subsequent protein body isolation. The supernatant was further centrifuged for 10 min in a Sorvall SS34 rotor to yield a $37,000 \times$ $\mathrm{g}_{\mathrm{av}}$ membrane pellet.

The $10,000 \times \mathrm{g}_{\mathrm{av}}$ band was incubated with $30 \mathrm{~mm}$-EDTA (final concentration) for $20 \mathrm{~min}$ prior to fractionation on (A) sucrose or (B) Percoll density gradients.

(A) A sample, equivalent to 1.4 spikes of starting material, diluted to $2 \mathrm{ml}$ in $\mathrm{HK}$ buffer $\mathrm{B}$, was layered on a $34 \mathrm{ml} 20-70 \%$ sucrose gradient made up in HK buffer $B$ and centrifuged at $96,000 \times \mathrm{g}_{\mathrm{av}}$ for $30 \mathrm{~min}$. The gradient was tapped from the top and monitored for absorbance at $280 \mathrm{~nm}$. Fractions of $1.25 \mathrm{ml}$ were collected and their sucrose density determined by 
refractometry (cf. Fig. 1). The major $280 \mathrm{~nm}$ peak was pooled, diluted in HK buffer B, centrifuged in a Sorvall SS34 rotor at 37,000 $\times$ $\mathrm{g}_{\mathrm{av}}$ for $20 \mathrm{~min}$ and the pellet retained for transmission electron microscopical analysis.

(B) A sample, equivalent to 2-6 spikes of starting material, was added to a $45 \%$ Percoll suspension to a final volume of $23 \mathrm{ml}$. A $45 \%$ Percoll colloid was prepared by mixing 1 part HK buffer $\mathrm{C}$ with 9 parts Percoll to adjust the osmolarity to $320 \mathrm{mOs} / \mathrm{kg} \mathrm{H}_{2} \mathrm{O}$, and then diluting with $\mathrm{HK}$ buffer $\mathrm{B}$ and sample to give a starting density of $1.085 \mathrm{~g} \cdot \mathrm{ml}^{-1}$. A self-generated gradient was formed by centrifugation in a Beckman $60 \mathrm{Ti}$ rotor at $40,000 \times \mathrm{g}_{\mathrm{av}}$ for 20 min (excluding acceleration/deceleration time). Percoll colloids containing a set of 9 coloured density marker beads were centrifuged in parallel to monitor the form of the density gradient. The gradient was tapped from the top and two fractions collected and diluted with HK buffer B (cf. Fig. 3). Fraction 1, banding at a density of 1.05 g. $\mathrm{ml}^{-1}$ (approximately 0\% Percoll), was centrifuged at $37,000 \times \mathrm{g}_{\mathrm{av}}$ in a Sorvall SS34 rotor and the pellet was washed in buffer and collected for further analysis. Fraction II, banding at a density of $1.13 \mathrm{~g} \cdot \mathrm{ml}^{-1}$, was centrifuged at $10,000 \times \mathrm{g}_{\mathrm{av}}$ leaving Percoll in suspension and the pellet washed and collected for further analysis.

\subsection{Electron microscopy of subcellular fractions from barley endosperm}

Endosperm subcellular fractions, namely the $37,000 \times \mathrm{g}$ membrane pellet and fractions derived from the sucrose and Percoll density gradients, were diluted in their isolation buffers and fixed with $2 \%$ glutaraldehyde for $1 \mathrm{~h}$ at 0 ${ }^{\circ} \mathrm{C}$. The fixed material was pelleted at $10,000 \times$ $\mathrm{g}_{\mathrm{av}}$ and resuspended in $60 \mathrm{~mm}$-phosphate buffer, pH 7.3, containing 2\% glutaraldehyde. After a further hour, the material was centrifuged at $10,000 \times \mathrm{g}_{\mathrm{av}}$ and the pellet given three $10 \mathrm{~min}$ washes in the phosphate buffer and then postfixed with $1 \%$ osmium tetroxide in the same buffer. The fixed pellets were divided into 1.5 $\mathrm{mm}$ cubes, given four $5 \mathrm{~min}$ washes in distilled water and stained with $2 \%$ aqueous uranyl acetate for $3 \mathrm{~h}$ at $60{ }^{\circ} \mathrm{C}$. The specimens were then dehydrated through an alcohol series at room temperature and embedded in Spurr's lowviscosity epoxy resin. Sections were cut with a Reichert UM-2 microtome, then contrasted with lead citrate and examined in a Siemens Elmiskop 102.

\subsection{SDS-PAGE of protein body and membrane fractions isolated from barley endosperm}

The total polypeptide and the alcohol-soluble and insoluble polypeptide composition of isolated endosperm cell fractions was examined in duplicate preparations. Alcohol-soluble polypeptides were extracted with $60 \%$ isopropanol and $2 \% \beta$-mercaptoethanol at $60{ }^{\circ} \mathrm{C}$ for $2 \mathrm{~h}$ and dried down in an $\mathrm{N}_{2}$ stream. All samples were then suspended in $40 \mathrm{~mm}$-Tris base, $0.02 \%$ bromophenol blue, 13\% sucrose, 2\% SDS and $10 \mathrm{~mm}$-DTT and dissolved by boiling for $1 \mathrm{~min}$. The samples were acetylated in $36 \mathrm{~mm}$-iodoacetate $2 \mathrm{~h}$ prior to electrophoresis, using a $12.5 \%$ polyacrylamide gel in a Tris-borate $(\mathrm{pH} 8.64)$ buffer system. The proteins were visualized by staining with Coomassie Brilliant Blue R250 in 50\% methanol and 5\% acetic acid followed by partial destaining in the same solvent and then in 10\% TCA (20). Hordein polypeptides extracted from Bomi and Carlsberg II barley flour were kindly provided by J. INGVERSEN and J. M. SCHMITT.

\section{RESULTS}

\subsection{Isolation of protein bodies by sucrose density gradient centrifugation}

Centrifugation of ground endosperm of Bomi barley at $10,000 \times \mathrm{g}$ according to the procedure detailed under 2.3. yields a fraction enriched in protein bodies. After treatment of this fraction with EDTA for removal of ribosomes from the microsomal membranes, it can be further fractionated on a continuous sucrose density gradient into two bands absorbing at $280 \mathrm{~nm}$ (Figure 1). The smaller peak at $18 \%$ sucrose (1.05-1.07 g. ml-1 density) contains according to previous analyses ( 5 ) ribosomal subunits and the larger peak at $40 \%$ sucrose (1.18 g. ml-1 density) was analyzed by electron microscopy. Besides protein bodies, profiles of smooth or stripped microsomes are recognizable in addition to some 


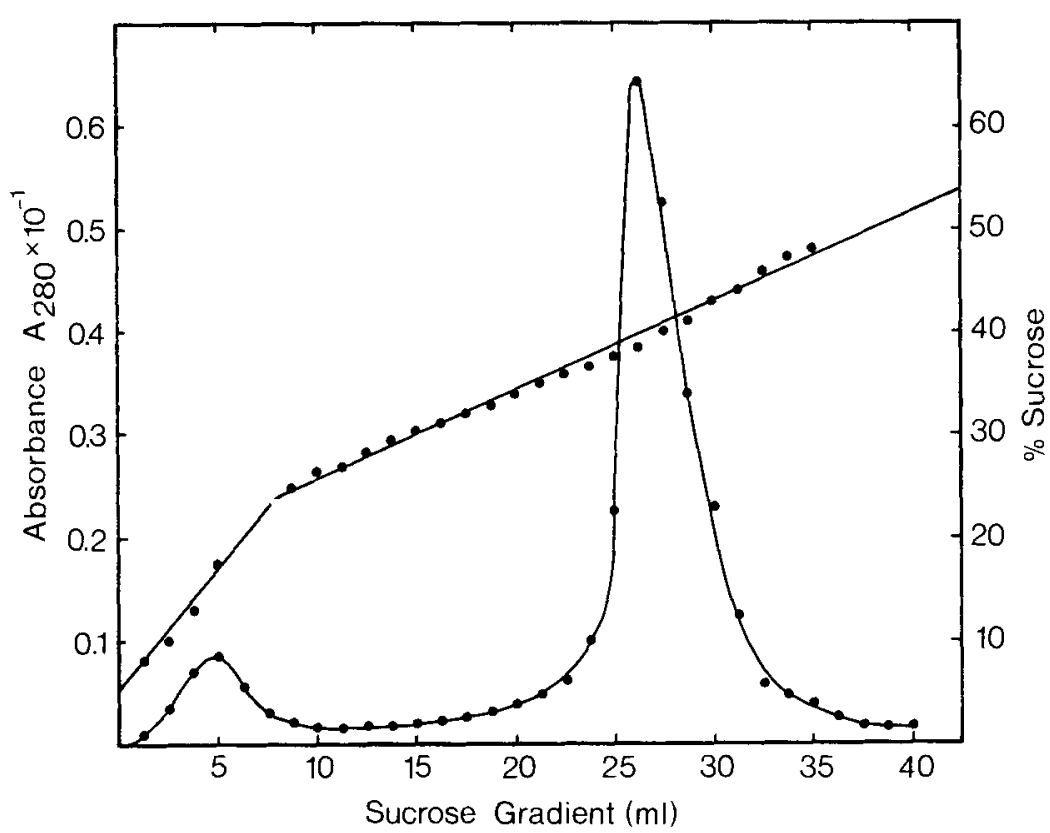

Figure 1. Sucrose density profile of the $10,000 \times \mathrm{g}$ fraction from Bomi barley endosperm.

An endosperm cell fraction was banded onto a $2.26 \mathrm{M}$-sucrose cushion by centrifugation at $10,000 \times \mathrm{g}$ for 20 min, collected and treated with $30 \mathrm{~mm}$-EDTA for $30 \mathrm{~min}$. A $2 \mathrm{ml} \mathrm{sample} \mathrm{in} \mathrm{HK} \mathrm{buffer} \mathrm{B} \mathrm{was} \mathrm{layered} \mathrm{on} \mathrm{a} 20-$ $70 \%$ continuous sucrose gradient prepared in HK buffer B and centrifuged for $30 \mathrm{~min}$ at $96,000 \times \mathrm{g}$.

rough microsomes remaining after incomplete detachment of ribosomes from the rough endoplasmic reticulum (Figure 2). Alternative techniques for the isolation of protein bodies were therefore explored.

\subsection{Isolation of protein bodies by Percoll density gradient centrifugation}

The protein body enriched $10,000 \times \mathrm{g}$ fraction from Bomi barley endosperm separated isopycnically into two sharp bands in a Percoll density gradient (Figure 3). A sigmoidal gradient generated in situ, was specifically designed to achieve maximum separation of these bands by adjustment of the starting density and centrifugation conditions. Fraction II, found at a density of $1.13 \mathrm{~g} . \mathrm{ml}^{-1}$, comprised almost exclusively protein bodies (Figure 4). Fraction I, banding at a density of $1.05 \mathrm{~g} . \mathrm{ml}^{-1}$, was shown to contain stripped and smooth microsomes and oleosomes (Figure 5).

The initial $10,000 \times \mathrm{g}$ fraction contains the majority of the protein bodies. Higher centrifugal forces $(37,000 \times \mathrm{g})$ recovered some small protein bodies, but pelleted mainly rough microsomes and oleosomes (Figure 6).

Treatment of the initial $10,000 \times \mathrm{g}$ fraction with EDTA was essential for obtaining a pure protein body fraction in the Percoll gradient. If the pre-treatment with EDTA was omitted, the rough microsomes co-migrated with the protein bodies to a density of $1.13 \mathrm{~g} \cdot \mathrm{ml}^{-1}$. The composition of this fraction in such an experiment is shown in Figure 7.

The clean separation of intact protein bodies from cytoplasmic membranes by isopycnic centrifugation in a Percoll density gradient can accordingly be attributed to the following features of the procedure. Cell breakage for the release of endosperm protein bodies was restricted to grinding the tissue with pestle and mortar in liquid nitrogen. Further homogenization in a Potter-Elvehjem homogenizer was avoided to preserve the compound structure of protein bodies at the expense of incomplete cell breakage 


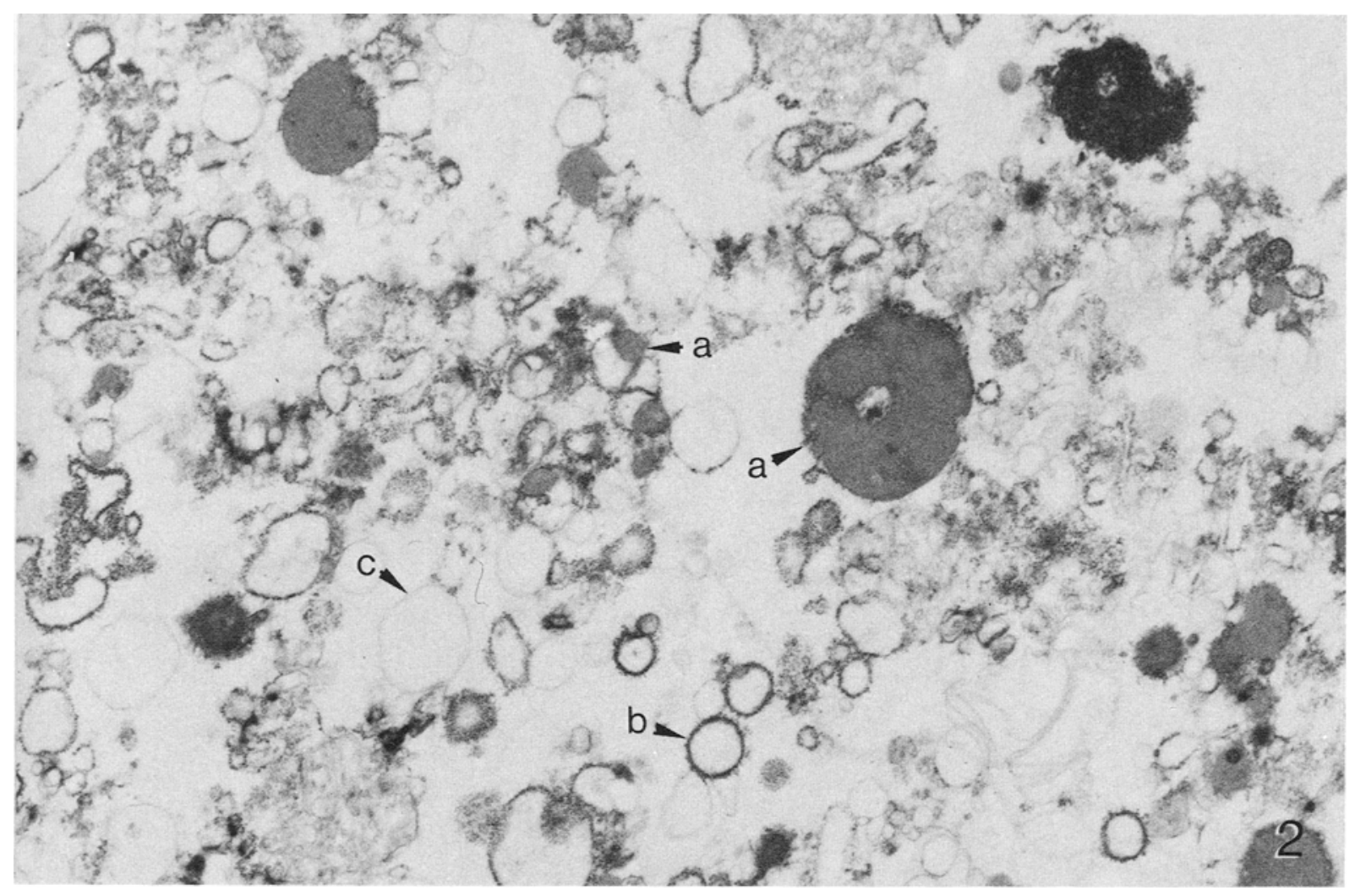

Figure 2. Electron micrograph of section through the material banding at $40 \%$ sucrose in a gradient as presented in Figure 1.

Protein bodies (a), rough microsomes (b) and smooth or stripped microsomes (c) can be discerned. Magnification: $\times 15,000$.

and consequent low recoveries. While a small proportion of the protein bodies were pelleted during the initial $500 \times \mathrm{g}$ centrifugation, the majority of the population were sedimented at $10,000 \times \mathrm{g}$. This fraction was collected by centrifugation from the surface of a sucrose

Figure 3. Isolation of protein bodies from Bomi barley endosperm by Percoll density gradient centrifugation.

A $10,000 \times g$ fraction derived from endosperm tissue was separated on a Percoll density gradient (45\% Percoll in HK buffer B) generated in situ by centrifugation in a Beckman 60 Ti rotor at $40,000 \times$ $\mathrm{g}$ for $20 \mathrm{~min}$. Isopycnic fractionation yielded two visible bands, Fractions I and II, respectively.

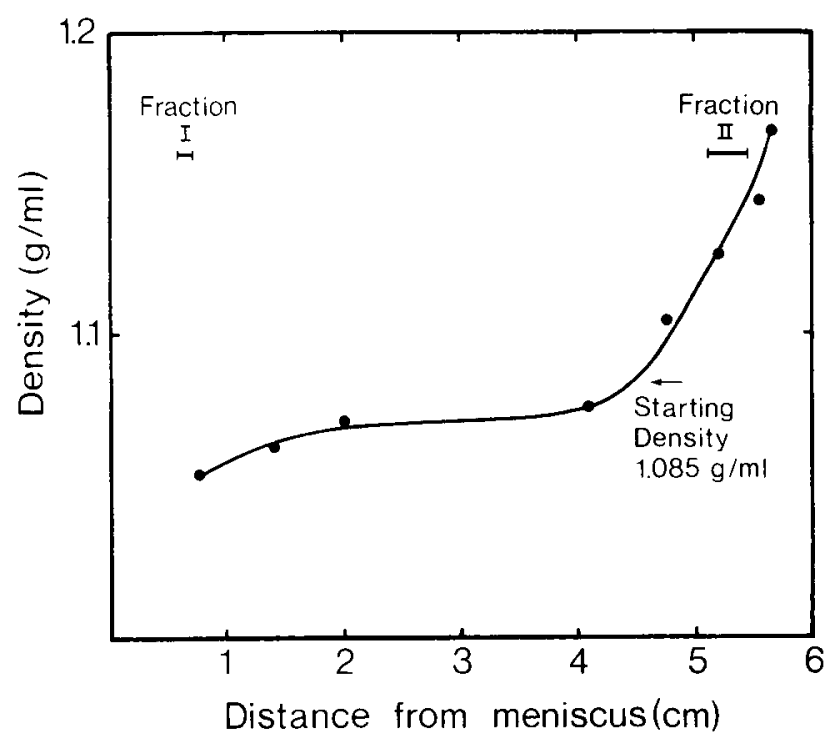



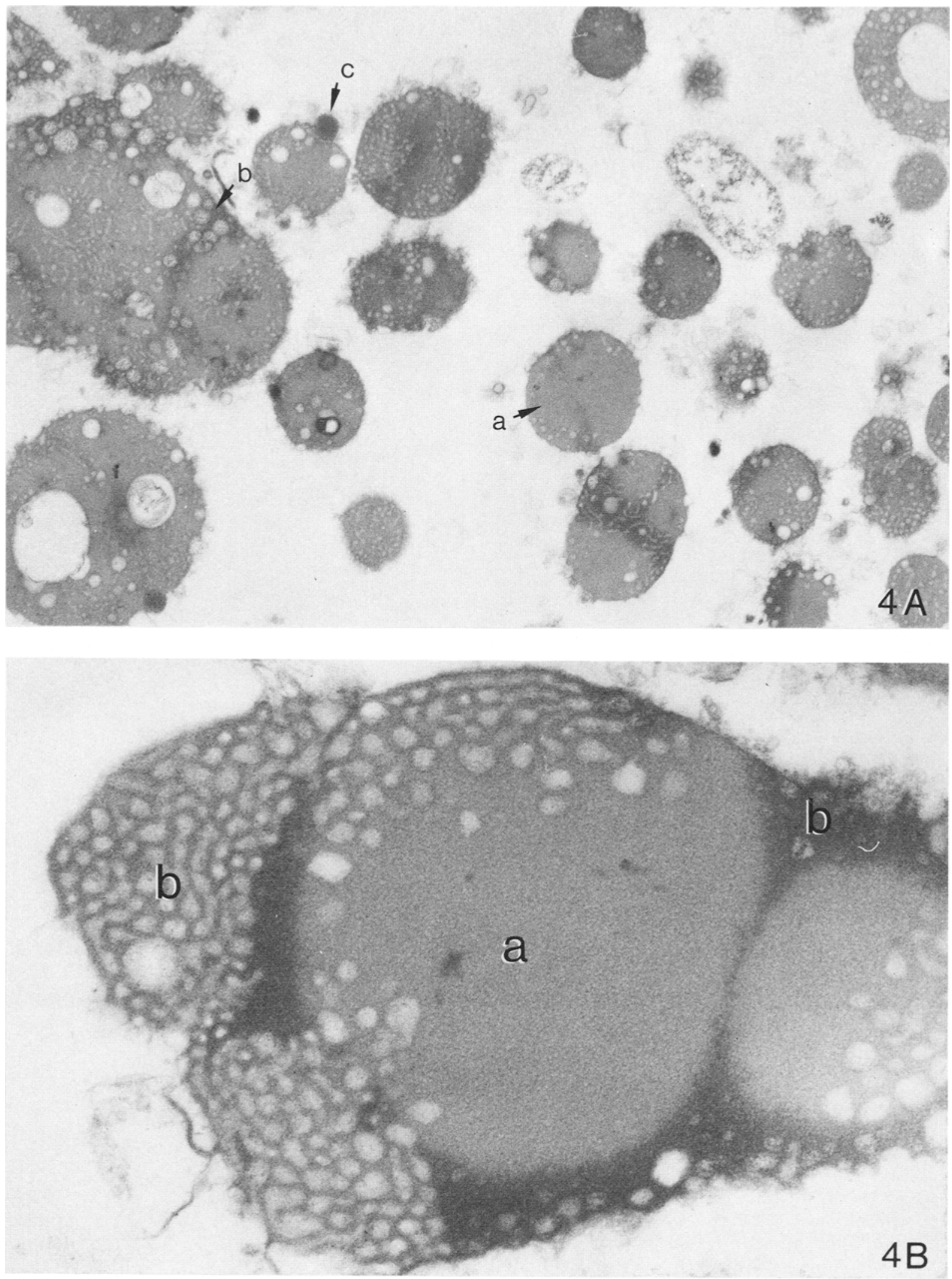

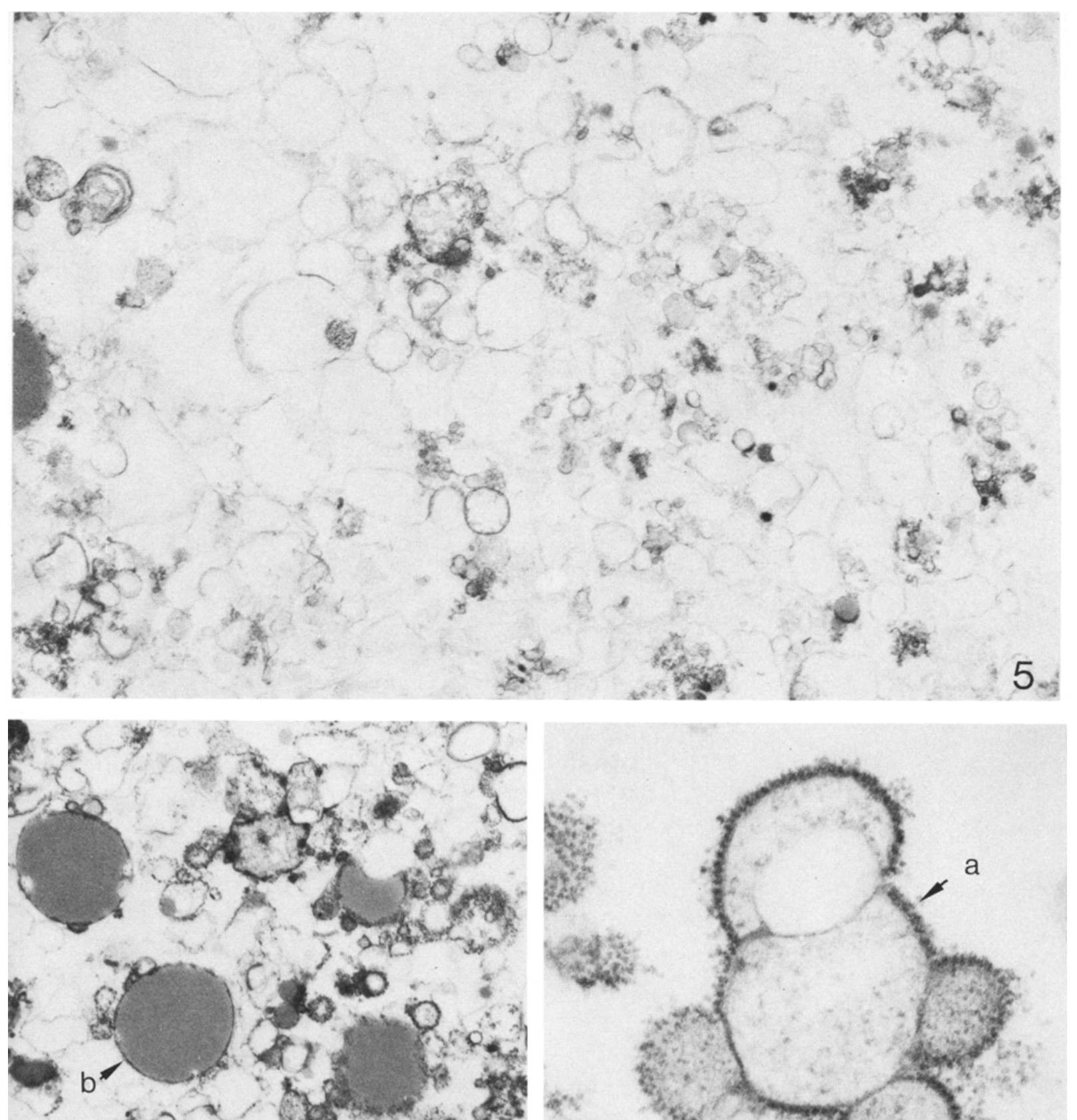

20 $0^{2}-2$

- . T. To dest

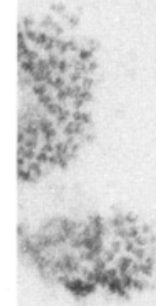

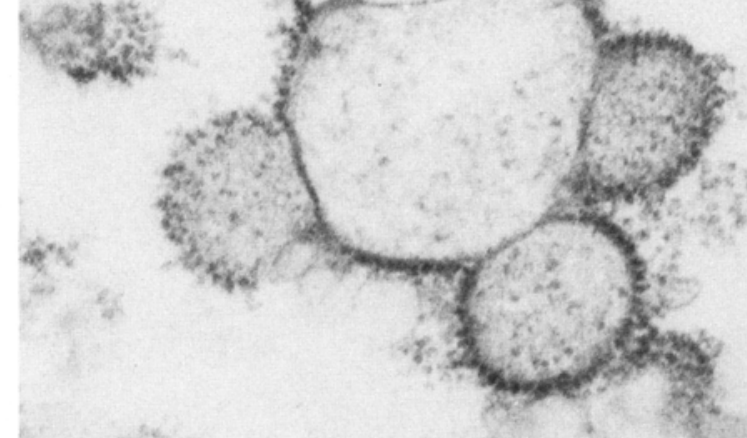

* $20^{\circ}$ $\infty 0^{2} 0^{-a}$ to 11

$f^{*} x^{\circ} 0^{\circ} 06$

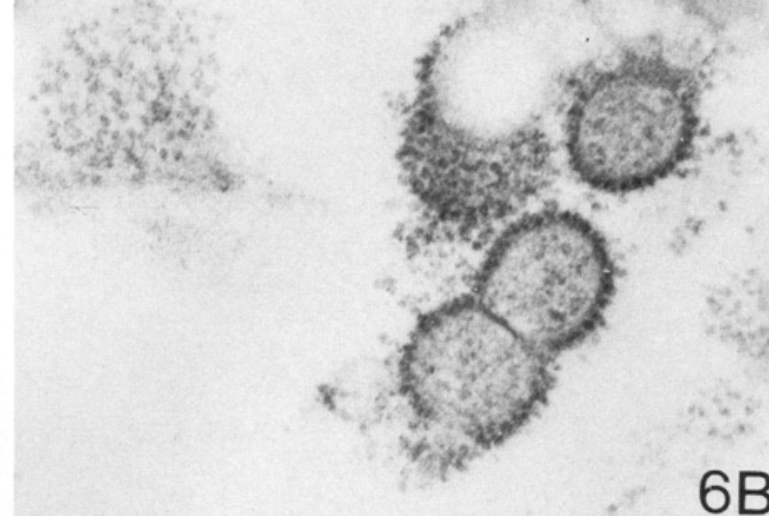


Figure 4. Electron micrographs of protein bodies isolated in Fraction II of the Percoll density gradient depicted in Figure 3.

This contained a pure preparation of protein bodies in which the homogeneous component (a) and fibrillar matrix (b) rarely associated with electron-dense spheres (c), can be discerned. Magnification: $\mathrm{A}=\times 15,000$; $\mathrm{B}$ $=\times 60,000$.

Figure 5. Electron micrograph of Fraction I from a Percoll density gradient (cf. Figure 3) reveals this band to comprise predominantly smooth and stripped microsomes. Magnification: $\times 15,000$.

Figure 6. Composition of the $37,000 \times \mathrm{g}$ fraction from Bomi barley endosperm. A $37,000 \times \mathrm{g}$ fraction was isolated from endosperm tissue after removal of material sedimented at $10,000 \times \mathrm{g}$.

The micrograph shows the $37,000 \times \mathrm{g}$ pellet to contain a mixture of rough microsomes (a) and oleosomes (b). Magnification: $\mathrm{A}=\times 15,000 . \mathrm{B}=\times 60,000$.

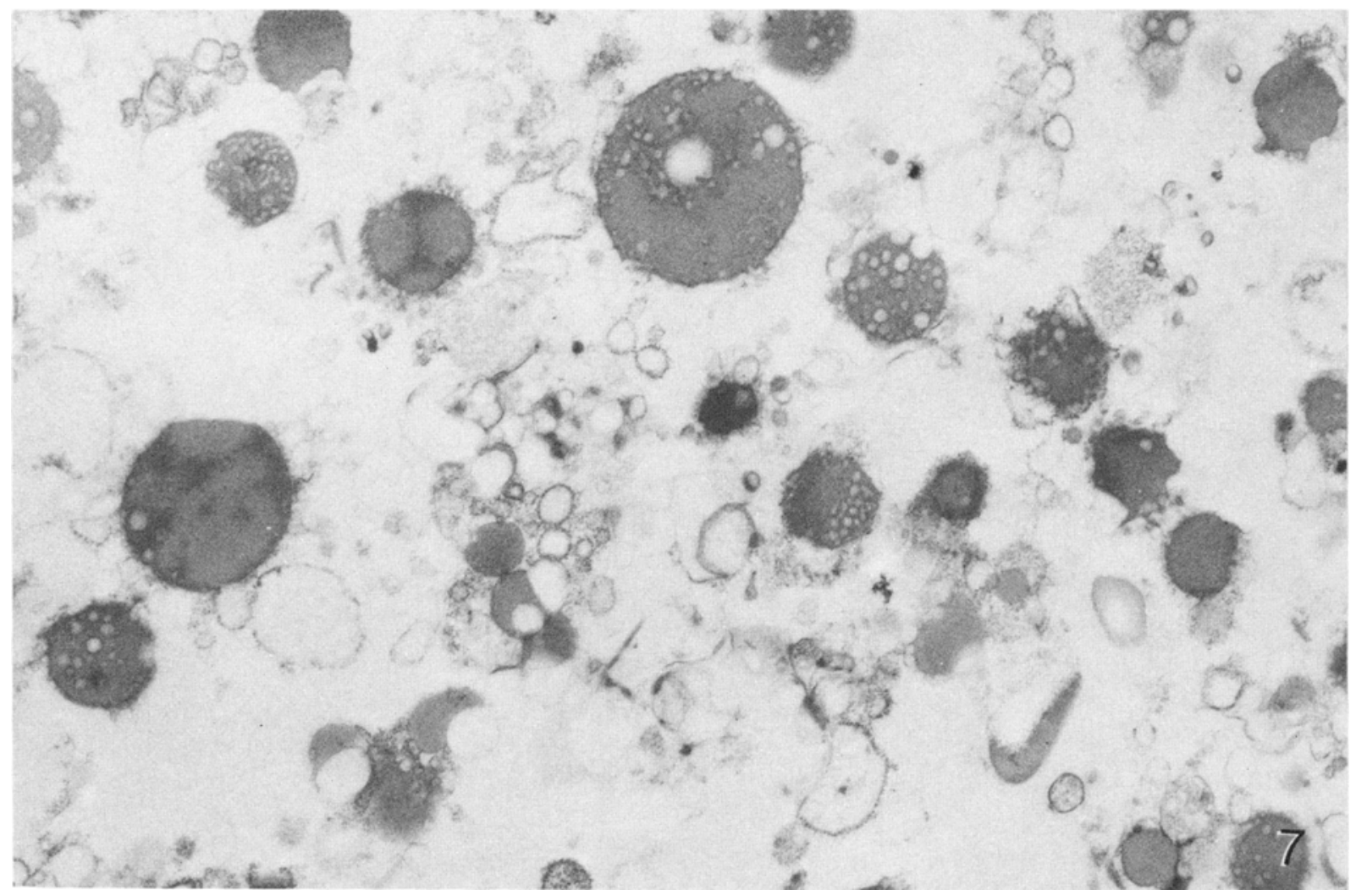

Figure 7. Electron micrograph of a section through Fraction II obtained by isopycnic banding in a Percoll density gradient comparable to that of Figure 3, but with the omission of EDTA from all stages of the isolation procedure.

Without EDTA treatment Fraction II contains a mixture of protein bodies and rough microsomes. Magnification: $\times 15,000$.

Figure 8. Protein bodies isolated from mutant Risø 1508 barley endosperm by Percoll density gradient centrifugation.

Protein bodies were isolated as described under 2.3. and Figure 3. The protein bodies are largely fibrillar in structure (b), frequently associated with electron-dense spheres (c). Magnification: $A=\times 15,000$, $\mathrm{B}=\times 60,000$. 


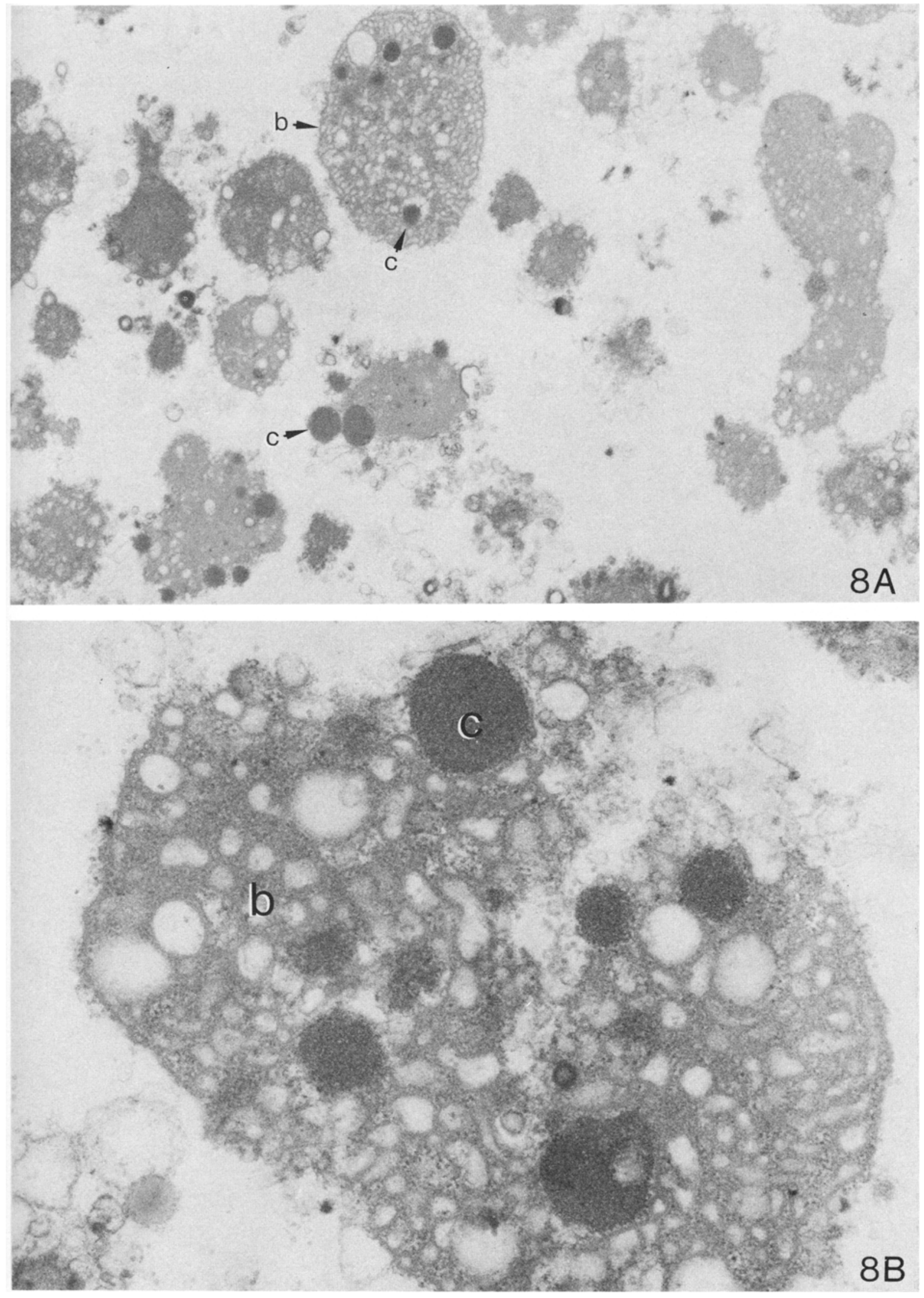


V. Cameron-Mills: Purified protein bodies from barley
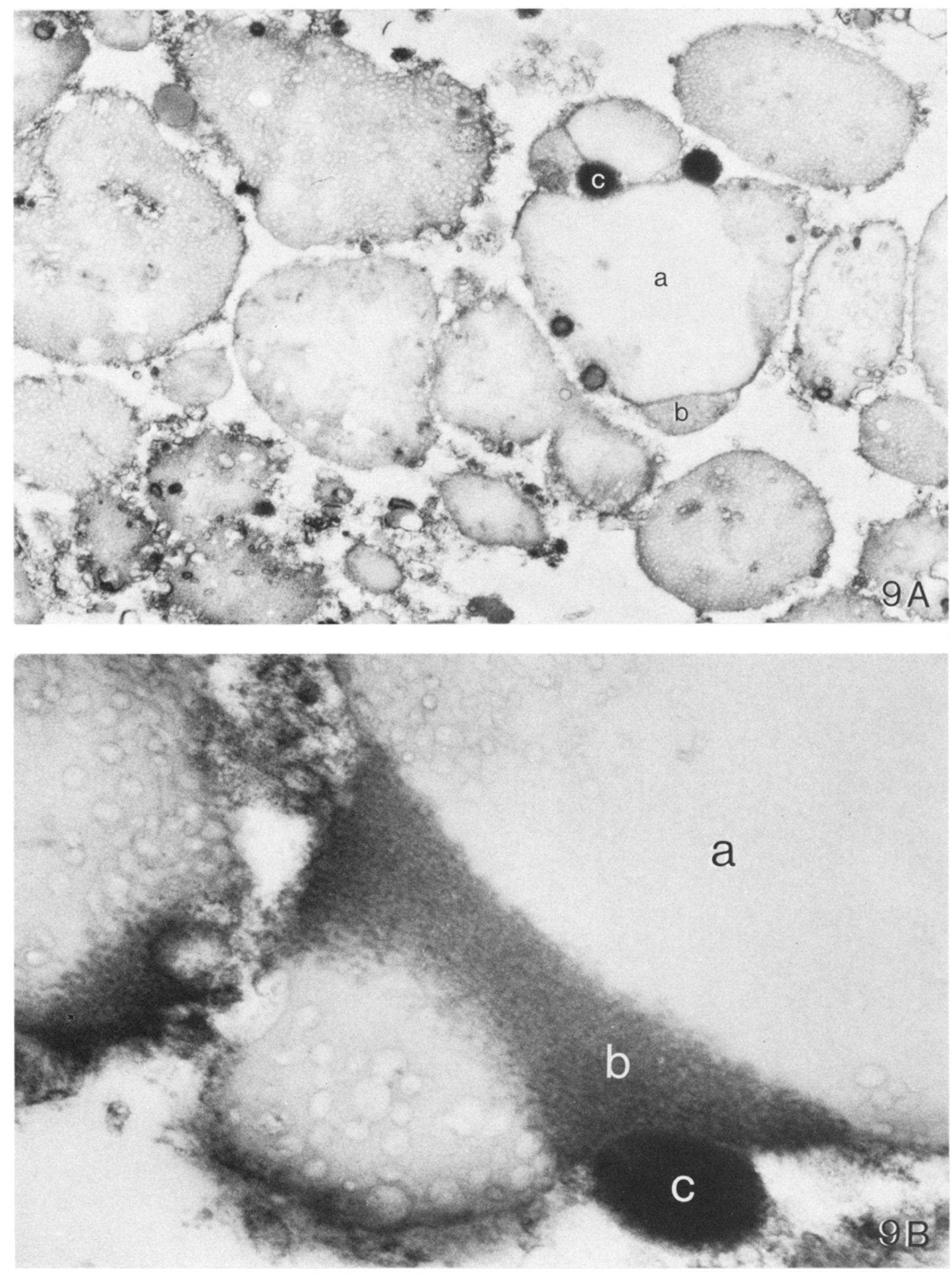
V. Cameron-Mills: Purified protein bodies from barley
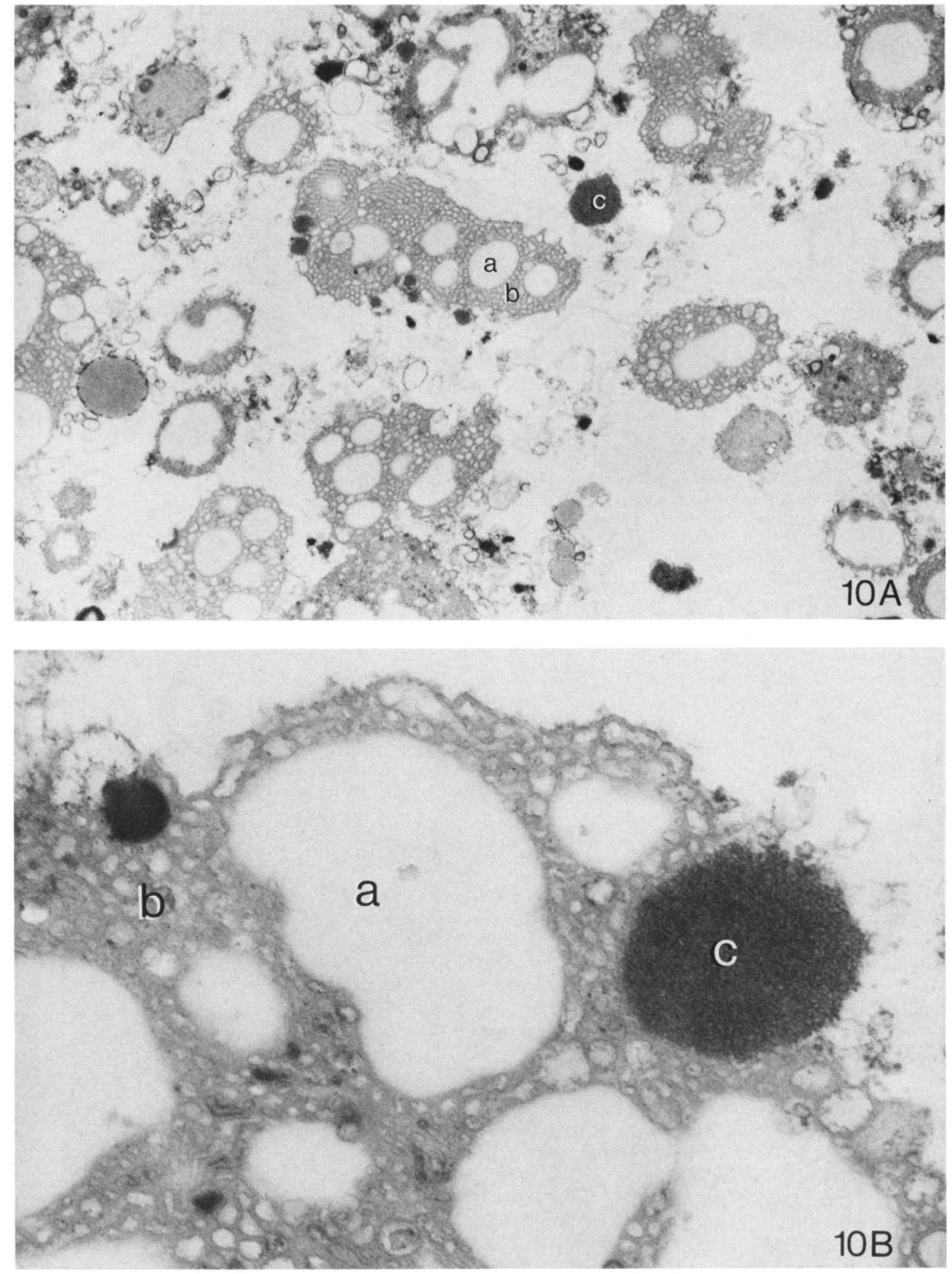
Figure 9. Protein bodies isolated from Carlsberg II barley endosperm by Percoll density gradient centrifugation.

Protein bodies were isolated from endosperm tissue as described under 2.3. and Figure 3. A homogeneous component (a) with a fibrillar periphery (b) and electron-dense spheres (c) can be distinguished. Magnification: $\mathrm{A}=\times 15,000 . \mathrm{B}=\times 60,000$.

Figure 10. Protein bodies isolated from endosperm of barley mutant Risø 56 by Percoll density gradient centrifugation.

Protein bodies were isolated from endosperm tissue as described under 2.3. and Figure 3. A homogeneous component (a) embedded in a fibrillar matrix (b) and associated with electron-dense spheres (c) can be seen. Magnification: $\mathrm{A}=\times 15,000$. $\mathrm{B}=\times 60,000$.

cushion as against a pellet. Compaction of the protein bodies and the aggregation of these hydrophobic structures with the membrane components was thereby avoided. Removal of ribosomes from the rough microsomes overcomes the complication that these band at the same density as the protein bodies.

\subsection{Ultrastructure of isolated protein bodies from wild type and high-lysine barley mutants}

Isopycnic banding of the $10,000 \times \mathrm{g}$ fraction from both wild type and mutant barley endosperm in the Percoll gradient were identical. Protein bodies were isolated from the endosperm tissue of Bomi, mutant Risø 1508, Carlsberg II and mutant Risø 56. Fraction II (Figure 3) from each Percoll gradient was analysed by transmission electron microscopy as shown in Figures 4 and 8 to 10 . The protein bodies in developing barley endosperm have a complex structure which has been interpreted as clusters of homogeneous components (a), embedded in a granular or fibrillar matrix (b), frequently associated with electron-dense spheres (c) (17, 25). All three components have been preserved in the isolated protein bodies as is seen most clearly in Figures 4, 9 and 10. Certain changes in ultrastructure have occurred during the isolation procedure leading frequently to a more open structure in the fibrillar matrix and a sponge-like appearance of the homogeneous component. The similarity of these two structures suggests that the homogeneous portion is a compacted form of the fibrillar matrix, which can dissociate during isolation. The peripheral matrix seen at high magnification (Figures $4 \mathrm{~B}$ and $10 \mathrm{~B}$ ) comprises a fine network of fibrils in which form the hordein polypeptides may first be precipitated.

Within the endosperm tissue, protein bodies are found in vacuoles, which are bordered by the tonoplast membrane $(17,25)$. The absence of a tonoplast around purified protein bodies suggests that the vacuole is ruptured during the isolation procedures. Protein bodies of the developing endosperm are characteristically associated with numerous membrane vesicles which lie near the surface or within the structure of the protein body. Such vesicles are also recognizable at the surface and inside the purified protein bodies (Figures 4, 7, 8, 9, 10).

In protein bodies from Bomi and Carlsberg II barley the homogeneous component is predominant, matrix material being restricted to the immediate periphery of the single or aggregated homogeneous deposits (Figures 4 and 9). Small, electron-dense spheres are rare components of these isolates. Protein bodies of the mutant 1508 with repressed hordein synthesis have a reticulate appearance, lack defined homogeneous components and contain prominent electrondense spheres (Figure 8). With the deficiency in hordein the condensation of storage polypeptides into protein bodies proceeds in an altered manner. Protein bodies from mutant 56 are deficient in B hordein polypeptides. Here, the homogeneous components, which are fewer than in wild type, are embedded in a large proportion of fibrillar matrix (Figure 10). The number of electron-dense spheres is comparable to that of wild type. 


\subsection{Polypeptide composition of protein bodies isolated from wild type and high-lysine barley mutants}

The polypeptide composition of protein bodies isolated from wild type and mutant barley endosperms has been analysed by SDS-PAGE. Both isopropanol-soluble and insoluble polypeptide components of protein bodies were studied in relation to the hordein composition of the respective wild type barley. In order to identify the origin of isopropanol-insoluble polypeptides present in protein body preparations, the polypeptide composition of the membrane fractions pelleted at 10,000 and $37,000 \times \mathrm{g}$ was also analysed.

Those hordein polypeptides present in Bomi barley (Figure 11, tracks 1,8), as defined by their solubility in $60 \%$ isopropanol, $2 \% \beta$ mercaptoethanol, are all to be found in isolated protein bodies (track 3). A number of additional polypeptides are present in isolated protein bodies (track 2), whose apparent molecular weight does not correspond to hordein polypeptides. Examination of the isopropanol-insoluble residue from the protein body fraction (track 4) reveals the presence of some of these nonhordein polypeptides as weakly staining bands. Membrane proteins in the $10,000 \times \mathrm{g}$ fraction, separated into Fraction I on the Percoll density gradient, are the greatest potential source of contamination of the protein body preparation. A comparison of the isopropanol-insoluble polypeptides (track 4) with the membrane proteins of Fraction I (track 5) indicates that some but not all may be such membrane proteins. They could conceivably derive from the membrane vesicles found at the surface of and inside the protein bodies. Analysis of the polypeptide composition of the $37,000 \times \mathrm{g}$ membrane pellet (track 6) confirmed that loss of protein bodies or components thereof (track 7) to this fraction was largely avoided.

The hordein composition of mutant Ris 1508 differs markedly from that of its wild type Bomi and is strongly reduced in amount $(3,22)$. The only isopropanol-soluble proteins in the grain are two ' $\mathrm{B}$ ' hordein polypeptides and a single ' $C$ ' hordein. Isoelectric focusing indicates that these hordein polypeptides may not necessarily correspond to those of similar apparent molecular weight in the wild type (22). These polypeptides were the only isopropanol-soluble components of the isolated mutant 1508 protein bodies (Figure 12, track 3). The heavy band of high apparent molecular weight, which is also present in the wild type, is thought to be a hordein aggregate.

A large number of isopropanol-insoluble polypeptides were present in the protein body fraction (tracks 2, 4). Unlike the wild type, the limited hordein polypeptide composition of mutant protein bodies greatly assisted the identification of these polypeptides. A comparison with membrane proteins in Fraction I (track 5 ), indicates that many may originate from cytoplasmic membranes. Interestingly, in electron micrographs of sections through protein bodies of the mutant $(17,25)$ their content of membrane vesicles appears more prominent (cf. Figure 8 ) than in the wild type. However, the isopropanol-insoluble residue is enriched with two polypeptides which are not prominent components of either the 10,000 or $37,000 \times \mathrm{g}$ membrane fractions (tracks 5 to 8), and these are regarded specific to protein bodies.

The hordein polypeptide composition of Carls-

Figure 11. Polypeptide composition of protein bodies from Bomi barley endosperm.

Protein bodies (Fraction II) and smooth and stripped microsomes (Fraction I) were isolated from endosperm tissue as described under 2.3. and Figure 3. The isopropanol-soluble and insoluble polypeptides $(60 \%$ isopropanol, $2 \% \beta$-mercaptoethanol extraction at $60^{\circ} \mathrm{C}$ for $2 \mathrm{~h}$ ) in these fractions and the $37,000 \times \mathrm{g}$ membrane pellet were examined. Samples were prepared for SDS-PAGE, electrophoresed on a $12.5 \%$ polyacrylamide gel, and subsequently stained with Coomassie Brilliant Blue.

Figure 12. Polypeptide composition of protein bodies from endosperm of barley mutant Risø 1508 .

Protein bodies (Fraction II), smooth and stripped microsomes (Fraction I) and the $37,000 \times \mathrm{g}$ membrane pellet were isolated and analysed by SDS-PAGE as described under 2.3. Arrows indicate non-hordein polypeptides specific to protein bodies. 
V. CAmeron-Mills: Purified protein bodies from barley
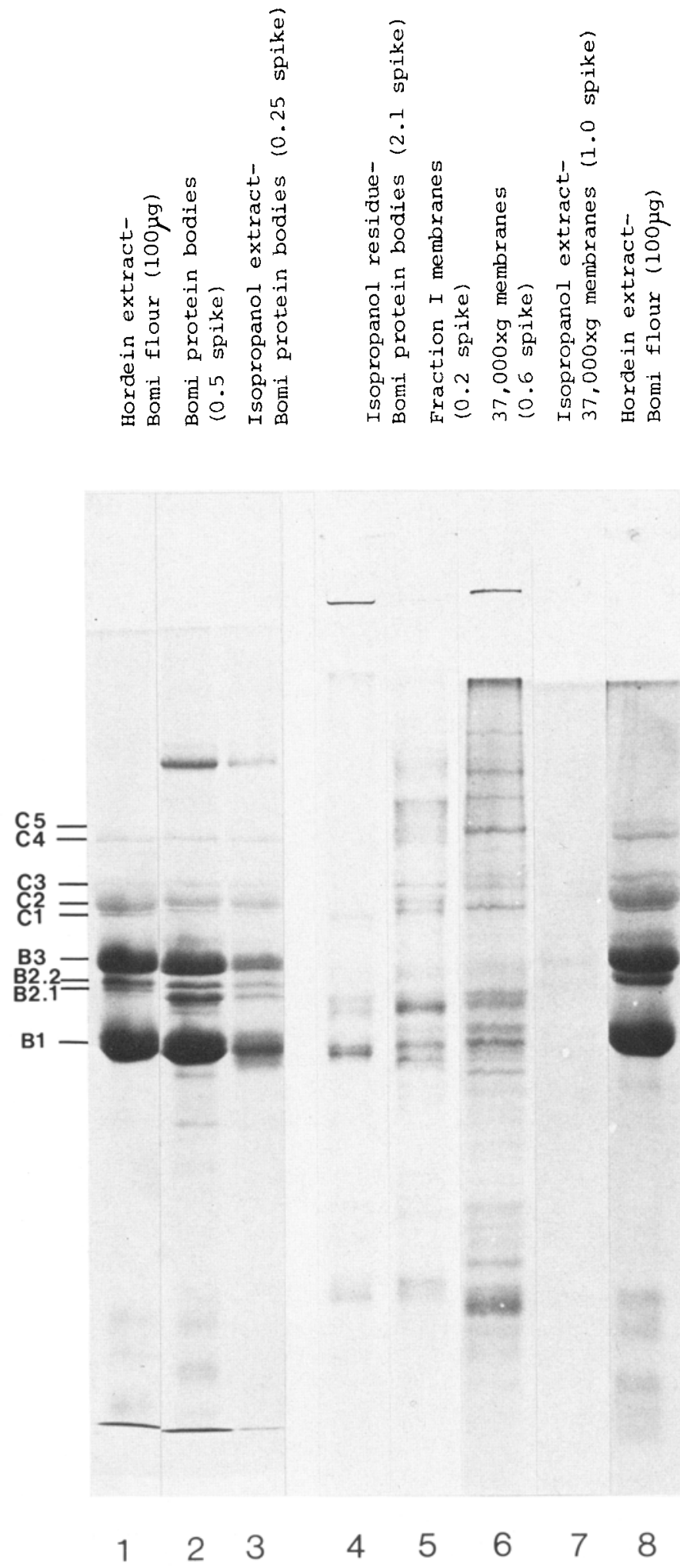

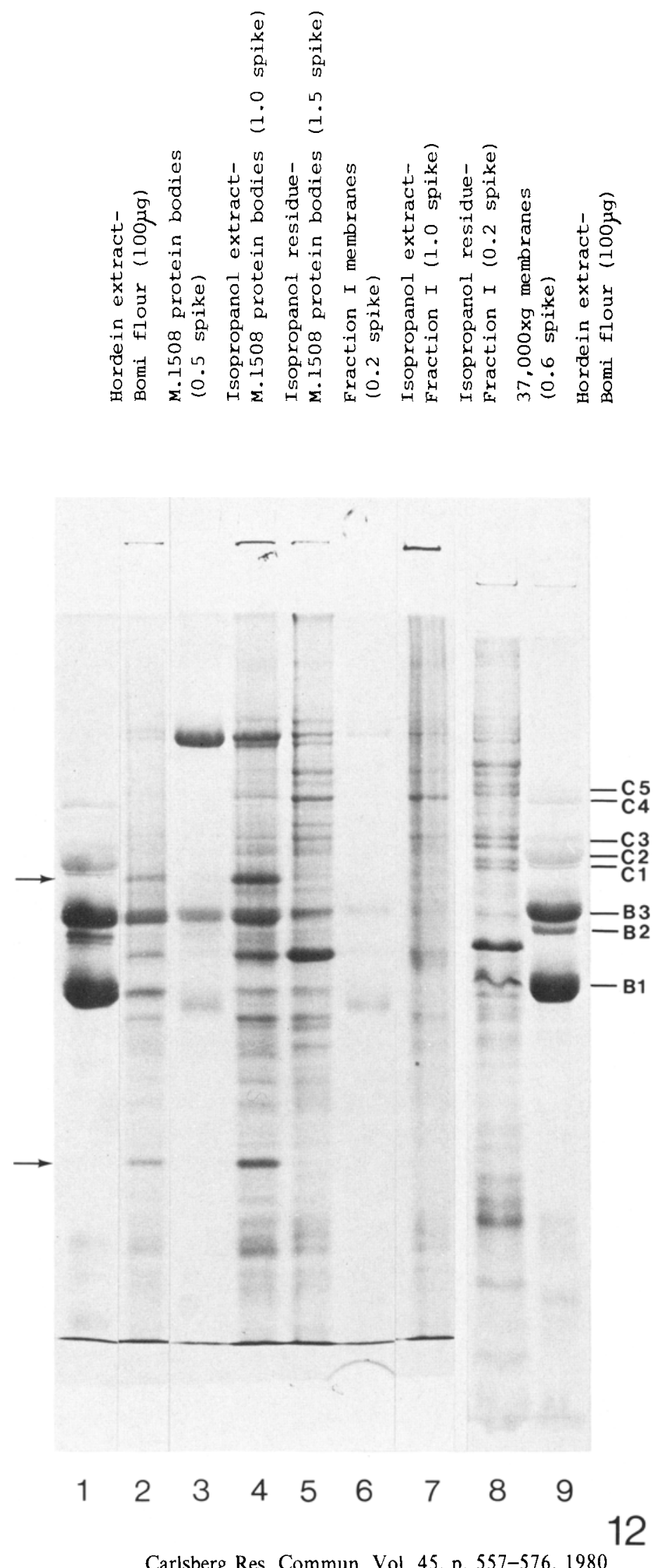


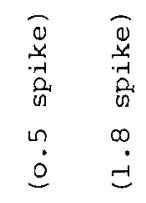

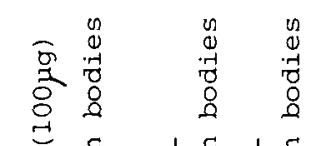

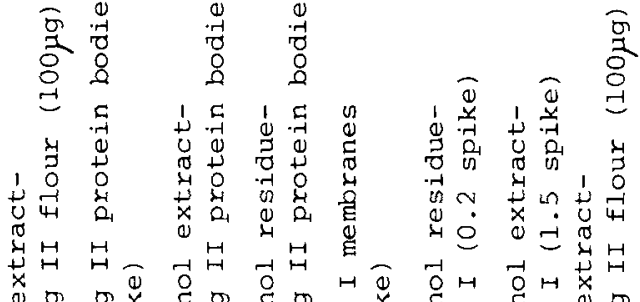

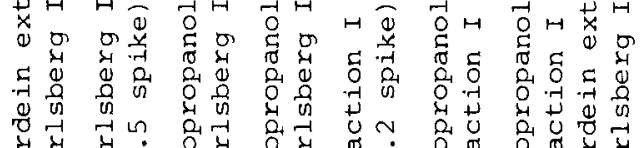

मे द्र

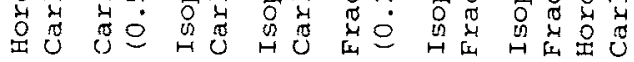

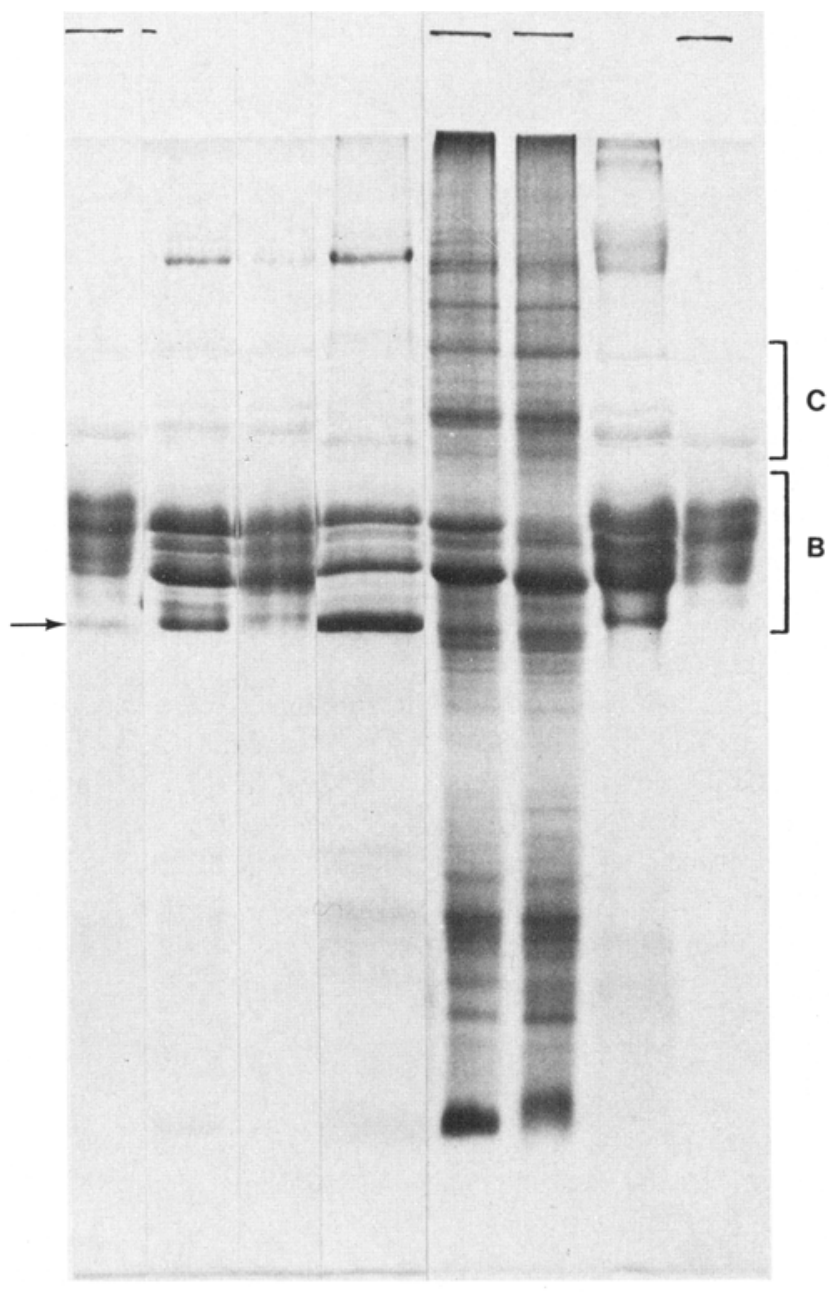

$\begin{array}{llllllll}1 & 2 & 3 & 4 & 5 & 6 & 7 & 8\end{array}$ 
V. CAmeron-Milis: Purified protein bodies from barley
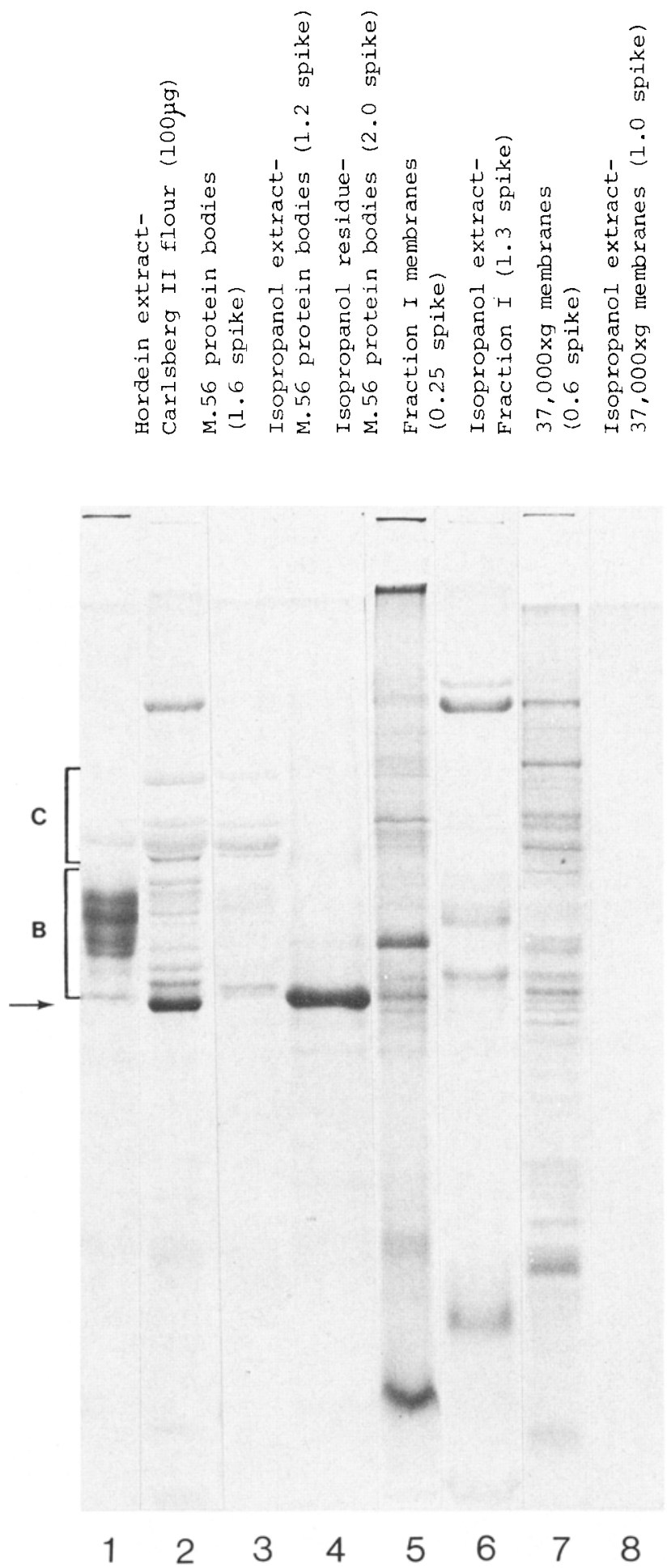
Figure 13. Polypeptide composition of protein bodies from Carlsberg II barley endosperm.

Protein bodies (Fraction II), smooth and stripped microsomes (Fraction I) were isolated and analysed by SDSPAGE as described under 2.3. Arrow indicates non-hordein polypeptide specific to protein bodies.

Figure 14. Polypeptide composition of protein bodies from endosperm of barley mutant Risø 56.

Protein bodies (Fraction II), smooth and stripped microsomes (Fraction I) and the $37,000 \times \mathrm{g}$ membrane pellet were isolated and analysed by SDS-PAGE as described under 2.3. Arrow indicates non-hordein polypeptide specific to protein bodies.

berg II barley has been characterized, and the ' $\mathrm{C}$ ' hordein polypeptides were found to have a similar electrophoretic mobility (SDS-PAGE) to those of Bomi barley (6). All of the hordein polypeptides (Figure 13, tracks 1,8) can be identified in protein bodies isolated from Carlsberg II endosperm (track 2) and their isopropanol extract (track 3). Although hordein extraction from the protein bodies was incomplete, the residue was enriched in a single polypeptide (track 4). This may be an integral protein body component since it is absent from the membrane proteins of Fraction I (tracks 5, 6). The presence of hordein in Fraction I (track 7) reflects a heavy contamination of Fraction I with protein bodies in this particular Percoll density gradient.

The 'B' hordein component of barley mutant 56 is much reduced with respect to the wild type Carlsberg II, and only a single 'B' hordein polypeptide is identifiable under non-reducing conditions (6). The ' $\mathrm{C}$ ' hordein polypeptides in mutant 56 are similar to wild type, and these and a few poorly resolved 'B' hordein polypeptides are all found in the isolated protein bodies (Figure 14, track 3). The isopropanol-insoluble residue of the protein bodies was greatly enriched in a single polypeptide (track 4), which had a similar electrophoretic mobility to the major polypeptide found in the residue of wild type protein bodies. This polypeptide was not a significant component of mutant 10,000 or $37,000 \times \mathrm{g}$ membrane fractions either (tracks 5,7 ). Since 'B' hordein polypeptides with similar electrophoretic mobilities are greatly reduced in the mutant, it is possible to identify this polypeptide as a major non-hordein component of wild type and mutant protein bodies. Although hordein polypeptides present in Fraction I (track 6) indicated some contamination of the $10,000 \times \mathrm{g}$ fraction with protein bodies, the
$37,000 \times \mathrm{g}$ fraction was devoid of protein body material (track 8).

\section{DISCUSSION}

Protein bodies have been isolated from the endosperms of the cereals maize $(4,13)$, wheat (16), rice (15) and barley $(10,18)$ employing the technique of sucrose density gradient centrifugation. Using similar methods, protein bodies from Bomi barley endosperm (20 days old) were found to band as a single peak on a sucrose density gradient at a density of $1.18 \mathrm{~g} \cdot \mathrm{ml}^{-1}$ (Figure 1). During barley endosperm development the isopycnic density of isolated protein bodies increases from $1.18 \mathrm{~g} \cdot \mathrm{ml}^{-1}(\mathrm{av})$ at 13 days after anthesis to $1.25 \mathrm{~g} \cdot \mathrm{ml}^{-1}(\mathrm{av}) 28$ days after anthesis (10). Rough microsomes from the endoplasmic reticulum of barley endosperm have an isopycnic density in sucrose density gradients of 1.20 g.ml-1 and stripped microsomes between 1.17 and $1.18 \mathrm{~g} \cdot \mathrm{ml}^{-1}(5)$ and these are therefore both major components of the $1.18 \mathrm{~g} . \mathrm{ml}^{-1}$ protein body peak.

A Percoll density gradient was found to be successful in separating 20 day old protein bodies from the membrane components of barley endosperm homogenates (Figure 3). In a sigmoidal density gradient, the protein bodies and rough microsomes banded isopycnically at 1.13 g. $\mathrm{ml}^{-1}$ and smooth or stripped microsomes at $1.05 \mathrm{~g} \cdot \mathrm{ml}^{-1}$. By including EDTA in the isolation buffers to strip ribosomes from the rough microsomes, a pure preparation of protein bodies was routinely obtained by this means. As previously found with sucrose gradients (10), the isopycnic density of protein bodies isolated from Bomi, mutant 1508, Carlsberg II and mutant 56 were also very similar in Percoll gradients.

The difference in bouyant density of protein 
bodies and microsomes in Percoll versus sucrose density gradients is similar to that observed with isolated intact plant nuclei and chloroplasts, both of which band at a lower density in silical sol (Ludox) gradients $(8,21)$. The apparent density of cell components in a sucrose density gradient may increase during sedimentation as they move through an environment of continuously rising osmolarity. Shrinkage of membrane-bound organelles in a hypertonic environment would in particular contribute to an increased density and this is expected to affect smooth microsomes more drastically than protein bodies and rough microsomes.

The heterogeneous structure of protein bodies seen in developing barley endosperm $(17,25)$ is preserved in the isolated protein body fractions. Protein bodies lie within vacuoles in the endosperm, and their isolation necessarily involves a change in their immediate environment. Since active starch biosynthesis in the endosperm depends on a steady supply of sucrose to the grain (11), which is predominantly stored in vacuoles (9) it is likely that the osmotic strength of the vacuoles is higher than the protein body isolation media. This factor, in addition to the effects of freezing and thawing of the grain, may have contributed to the sponge-like texture of the homogeneous component and the expansion of the fibrillar matrix. The similarity of structure and staining intensity of these two components (Figure 4B, 9B), supports the view that protein body formation involves the precipitation of hordein into a fibrillar network and its gradual condensation into a homogeneous structure (17). If this interpretation is correct, then a change in protein body composition resulting from the reduced synthesis of both ' $\mathrm{C}$ ' and ' $\mathrm{B}$ ' hordein polypeptides in mutant 1508 or ' $\mathrm{B}$ ' hordein polypeptides in mutant 56 , has significant repercussions on the dehydration and condensation of the storage proteins. Altered hordein composition and content appears to be related to decreased amounts of the homogeneous component. Further characterization of the electrondense spheres (Figures $4,8,9,10$ ) which are particularly numerous in the mutant protein body preparations, will depend on their independent isolation.

Barley protein bodies (Bomi and mutant 1508) are considered the storage site of all the major hordein polypeptides synthesized during endosperm development (10). An electrophoretic analysis of the polypeptide composition of protein bodies isolated and purified from Bomi and mutant 1508 barley endosperm and in addition Carlsberg II and mutant 56 barley, confirms this fully. Analysis of both the isopropanol-soluble (hordein) and insoluble polypeptides has revealed that certain polypeptides other than hordein are specifically associated with protein bodies. Two such polypeptides were prominently present in mutant 1508 protein body isolates, but weakly discernable in the wild type. A single isopropanol-insoluble polypeptide was a major component of mutant 56 protein bodies, and a polypeptide of similar electrophoretic mobility was found in Carlsberg II protein body preparations.

It has been suggested that the non-hordein polypeptides in barley protein bodies are glutelins since they would not be solubilized during the isolation procedures (10). Glutelins are present in the endosperm in significant amounts ( $25 \%$ and $37 \%$ of total seed $\mathrm{N}$ in Bomi and mutant 1508 barley, respectively) and have a complex polypeptide composition (24). In view of the insoluble nature of glutelins and the large amounts found in the endosperm, they may well have a storage function. It will be of interest to compare the composition and solubility properties of the non-hordein polypeptides in the protein bodies with glutelin as well as other seed proteins.

The application of this Percoll density gradient technique to the isolation of protein bodies from barley endosperm, at different stages of their development, will allow a closer investigation of the age dependent deposition of storage proteins. It will now also be possible to determine the precise nature and contribution of polypeptides other than hordein to protein body formation.

\section{ACKNOWLEDGEMENTS}

I would like to thank Professor D. von WeTtSTEIN, Dr. A. Brandt and Dr. J. IngVersen for valuable discussions throughout the course of this work. The assistance of JEAN SAGE in preparation of the electron micrographs is gratefully acknowledged. My research has been supported by a Wellcome Travelling Research 
Fellowship (1978/79) and the Carlsberg Laboratory $(1979 / 80)$.

\section{REFERENCES}

1. Blobel, G. \& B. Dobberstein: Transfer of proteins across membranes. II. Reconstitution of functional rough microsomes from heterologous components. J. Cell Biology 67, 852-862 (1975)

2. Bollini, R. \& M. J. Chrispeels: The rough endoplasmic reticulum is the site of reserveprotein synthesis in developing Phaseolus vulgaris cotyledons. Planta 146, 487-501 (1979)

3. BRANDT, A.: Endosperm protein formation during kernel development of wild type and a high-lysine barley mutant. Cereal Chemistry 53 , 890-901 (1976)

4. Burr, B. \& F. A. BurR: Zein synthesis in maize endosperm by polyribosomes attached to protein bodies. Proc. Nat. Acad. Sci. USA 73, 515-519 (1976)

5. Cameron-Mills, V. \& J. Ingyersen: In vitro synthesis and transport of barley endosperm proteins: Reconstitution of functional rough microsomes from polyribosomes and stripped microsomes. Carlsberg Res. Commun. 43, 471489 (1978)

6. DoLL, H.: A nearly non-functional mutant allele of the storage protein locus $\mathrm{Hor}^{-2}$ in barley. Hereditas 93, 217-222 (1980)

7. DolL, H. \& A. H. D. Brown: Hordein variation in wild (Hordeum spontaneum) and cultivated (H. vulgare) barley. Can. J. Genet. Cytol. 21, 391-404 (1979)

8. Henriks, A. W.: Purification of plant nuclei using colloidal silica. FEBS Lett. 24, 101-105 (1972)

9. Humphreys, T.: Dinitrophenol-induced efflux of sucrose from maize scutellum cells. Phytochemistry 16, 1359-1364 (1977)

10. InGversen, J.: Structure and composition of protein bodies from wild-type and high-lysine barley endosperm. Hereditas 81, 69-76 (1975)

11. Jenner, C. F. \& A. J. Rathuen: Factors regulating the accumulation of starch in ripening wheat grain. Aust. J. Plant Physiol. 2, 311-322 (1975)

12. KøIE, B. \& H. DoLl: Protein and carbohydrate components in the Risø high-lysine barley mutants. In $i$ Seed Protein Improvement in Cereals and Grain Legumes، Vol. I, IAEA, Vienna, pp. 205-215 (1979)

13. Larkins, B. A. \& W. J. Hurkman: Synthesis and deposition of zein in protein bodies of maize endosperm. Plant Physiol. 62, 256-263 (1978)
14. Larkins, B. A., K. Pedersen, A. K. Handa, W. J. Hurkman \& L. D. Smith: Synthesis and processing of maize storage proteins in Xenopus laevis oocytes. Proc. Nat. Acad. Sci. USA 76, 6448-6452 (1979)

15. Mitsuda, H., K. Murakami, T. Kusano \& K. YASUMOTO: Fine structure of protein bodies isolated from rice endosperm. Arch. Biochem. Biophys. 130, 678-680 (1969)

16. Morton, R. K., B. A. Paik \& J. K. Raison: Intracellular components associated with protein synthesis in developing wheat endosperm. Biochem. J. 91, 522-528 (1964)

17. Munck, L. \& D. von WetTstein: Effects of genes that change the amino acid composition of barley endosperm. In: Genetic Improvement of Seed Proteins. Proc. of a workshop 18-20 March, 1974. National Academy of Sciences, Washington D. C., pp. 71-82 (1976)

18. Ory, R. L. \& K. W. Henningsen: Enzymes associated with protein bodies isolated from ungerminated barley seeds. Plant Physiol. 44, 1488-1498 (1969)

19. Püchel, M., K. Müntz, B. Parthier, 0 . Aurich, R. Bassüner, R. Manteuffel \& P. SCHMIDT: RNA metabolism and membranebound polysomes in relation to globulin biosynthesis in cotyledons of developing field bean. Eur. J. Biochemistry 96, 321-338 (1979)

20. Sснмiтt, J. M.: Purification of hordein polypeptides by column chromatography using volatile solvents. Carisberg Res. Commun. 44, 431-438 (1979)

21. Sсhmitt, J. M., H.-D. BehnKe \& R. G. HerRmanN: Suitability of silica sol gradients for purification of cell organelles. Exp. Cell Res. 85, 63-72 (1974)

22. Shewry, P. R., A. J. Faulks \& B. J. Miflin: Effect of high-lysine mutations on the protein fractions of barley grain. Biochemical Genetics 18, 133-151 (1980)

23. Shewry, P. R., J. M. Field, M. A. Kirkman, A. J. FaulKs \& B. J. Mifun: The extraction, solubility, and characterization of two groups of barley storage polypeptides. J. Exp. Botany 31, 393-407 (1980)

24. Shewry, P. R., J. M. Hill, H. M. Pratt, M. M. LeGGATT \& B. J. MifLin: An evaluation of techniques for the extraction of hordein and glutelin from barley seed and a comparison of the protein composition of Bomi and Risø 1508. J. Exp. Botany 29, 677-692 (1978)

25. WetTstein, D. von: Biochemical and molecular genetics in the improvement of malting barley and brewers yeast. Proc. 17th Eur. Brewery Conv. Congr. Berlin 1979, 587-629 (1979) 